\title{
REMODELING OF THE INTERIOR OF PRESCHOOL INSTITUTIONS IN THE CONTEXT OF IMPROVEMENT OF AMBIENT VALUE AND QUALITY OF SPACE*
}

\author{
UDC 727.11:747=111
}

\author{
Vojislav Nikolić", Aleksandar Keković, Danica Stanković, Milan Tanić \\ University of Niš, Faculty of Civil Engineering and Architecture, Serbia \\ \#vojislavn@gmail.com
}

\begin{abstract}
Starting from the attitude that in conceiving, designing and equipping of the areas where children stay, the areas' quality becomes enriched, this paper treats the remodeling of the interior in the revitalization process of the existing preschool institutions. The issue was handled using the input of the critique and the studies of the psychological aspects of children's stay in preschool institutions. The basic goal of the research is finding of a practical model of interior space renovation in the preschool facilities in Nis, as in a typical urban environment. The innovation potential was analyzed on proposed remodeling of the interior of kindergarten „Bajka". The conclusions from this research can be used as guidelines for remodeling of the interior of other kindergartens built in the same period.
\end{abstract}

Key words: preschool institutions, revitalization, remodeling, innovation, interior.

\section{INTRODUCTION}

The main function of kindergarten facilities is to provide the complete care during the stay in the preschool facility, proper upbringing and education of the children and to stimulate them to perform creative activities freely. The aim of preschool education is to ensure healthy and happy childhood, conditions for positive physical, social, intellectual and emotional development and the basis for the uprising of stabile personality and further successful education of the youngest generation (Ivanović, 2000). The importance of the architectural concept of the kindergarten and its influence on the psychological development of the child must be taken very seriously (Stankovic, Stojić 2007). In order to

Received November 22, 2013

* Acknowledgement: This paper is realized within the third phase of the national scientific project at the University of Nis, The Faculty of Civil Engineering and Architecture, financed by Ministry of Science and Technological Development of the Republic of Serbia 2011-2014: Revitalization of preschool facilities in Serbia - The program and methods of environmental, functional, and energy efficiency improvement (No. 036045: leader of the scientific and research project Danica Stanković, PhD). 
achieve the necessary comfort of the users of preschool facilities, it is necessary for this space to fulfill certain requirements with the regard to functional, shape and materialization aspects. Keeping in mind the importance of the preschool period in the development of the healthy personality of a child and therefore the whole society, it is necessary to upgrade the comfort level of the existing kindergartens to the modern standards. This upgrade is done during the wider process of kindergarten improvement.

The Mark Dudek $(2000 ; 2005 ; 2008)$ opus, in architectural terms, provide short reviews of the issues encountered in preschool facilities and areas for the children's stay, and provide a view of the good quality contemporary architectonic practice. Mark Dudek as a researcher comments on and reflects the contemporary architectonic activities at the global level. There is a great number of researches related to the critique of the concepts, and suggestions for operational overcoming of immanent problems of psychological aspects of children's stay in preschool facilities. The most important contribution to the critique of the current forms of spatial organization of areas where children stay, are certainly the studies of the author such as Gary W.Evans (2004; 2006; 2007), Gary Moore (1985; 1994.) and Roger Hart (1979; 1997.). Certain researches are based on research of the elements of physical environment of preschool facilities, considering that they have strong influence on children's behavior. (Moore, 1987; Read, Sugawara \& Brandt, 1999, Weinstein, 1987; Wohlwill \& Heft, 1987). The studies of the professor Gery Moore (1986) confirmed that the quality of newly designed areas of preschool facilities, as a physical environment, affects the development results of the children, particularly their cognitive development and social behavior. The research of professor Stanković (2003; 2006 ; 2007; 2011.) was aimed at the relation of the set referential framework of psychological needs of children, in respect to the space where they stay, and the properties which should characterize it, for the purpose of improvement of ambient value and quality of space.

There are 20 kindergartens in the city of Niš that has a population of 300000 people. Most of these kindergartens were built during the 1970's and 1980's, and little has been invested in them since then (Petković, Kondić \& Tanić. 2012). These kindergartens do not fulfill the current standards in many aspects and thus need to be revitalized. The revitalization done so far has been limited to repainting the walls and repairing the roofs, while nothing has been done in order to improve the energy efficiency. The revitalization is desirable because of the unsatisfactory energy efficiency and inadequate functional aspects of these buildings. The process of revitalization is also a good opportunity to remodel the kindergartens in order to increase the ambient value of these buildings.

Several papers treated the problems of remodeling of kindergarten facades (Milošević, Nikolić \& Stanković, 2012; Nikolić, Milošević \& Stanković, 2013) while remodeling of the interior has not been dealt with to such extent. For this reason, the focus of this paper is on remodeling of the interior of preschool institutions, as one phase in the revitalization process, in the content of improvement of ambient values and space quality. These issues were approached on the basis of the critique and the studies of the psychological aspects of the children's stay in preschool facilities. Interior design in kindergartens has a direct effect on children's development (Trancik \& Evans, 1995), therefore their designers job is to study children's social and physical needs and design the interior space in order to respond to their needs. The initial position of the paper is that in conceiving, designing and equipping of the space for the children's stay, through architectonic articulation and realization in a material plane, the quality of the environment where children stay is improved. The subject matter of the paper is the research of the contemporary concepts and inter- 
ventions related to the design of the space for the children's stay in preschool facilities. The basic goal of the planned research is finding of a practical model of innovating the interior of the preschool institutions in Niš, as a typical urban environment. The innovation potential was analyzed on proposed remodeling of the interior of kindergarten „Bajka. In order to comprehensively analyze the subject matter the research and realize the set goal, the following methods were used: analysis and synthesis, modeling method, generalization and specialization, induction and deduction.

\section{ANALYSIS OF FOREIGN EXPERIENCE}

The designed elements of space can provide the support to the children, and help them function within the limits of their capacities, and still provoke the processes leading to the progress. (Stanković, 2008). One of the roles of the space in the preschool institution as a designed and built up environment, where children spend their time, is the contribution in the development of its abilities. It is a contribution of the space, primarily in enhancing the children capacities a certain level of its development, and its efficient interaction with the environment (Stanković, Milojković, \& Tanić, 2006).

Children centers take care of social and emotional development as well as of health of the youngest children. Nowadays, the preschool institutions are considered the educational institutions. Development of a child's personality, of its creativity, independence and social competences are the most important goals of preschool education. The designing of the kindergartens, therefore requires cooperation of architects, pedagogues and investors. The attractive looking building, with the clear arrangement of rooms where different material in natural condition is used, will help in development of children's curiosity and encourage them to start to explore themselves. The children experience their environment through their senses and they learn by doing. The idea of the space as third factor originates from the pedagogical approach by the Italian Regio Emilia (Edwards, 1993; Edwards, Gandini \& Forman, 1998). In this context, the preschool education means to make it possible for the children to learn through the experimenting process, in all domains. Free areas of the wall and deep benches set on the window frames, as in the example of the kindergarten in Vienna - Austria (Fig 1), provide the space for individual creative activities, and varying ceiling heights provide the children with the different and variable perception of space.

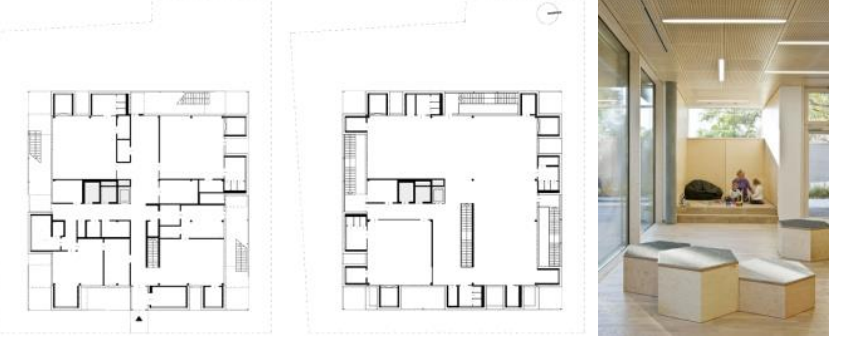

Fig. 1 Floor plans and interior - Crèche, Kindergarten and Childcare Centre in Vienna ${ }^{1}$

\footnotetext{
${ }^{1}$ http://www.detail-online.com/inspiration/creche-kindergarten-and-childcare-centre-in-vienna-106214.html, Retrieved November 2013
} 
Lightning can also contribute to the exciting experiencing of the space. Of course, as much as it is possible, the classrooms should have the natural light but uniform illumination is not always the advantage. Children sometimes prefer darker places where they can retire, when they feel the need for peace and quiet. Children often find the spots of artificial light more agreeable than the bright light, even than the ceiling light. Such approach is recognized in the design of the 8Units kindergarten interior, Velez Rubio - Spain (Fig. 2).

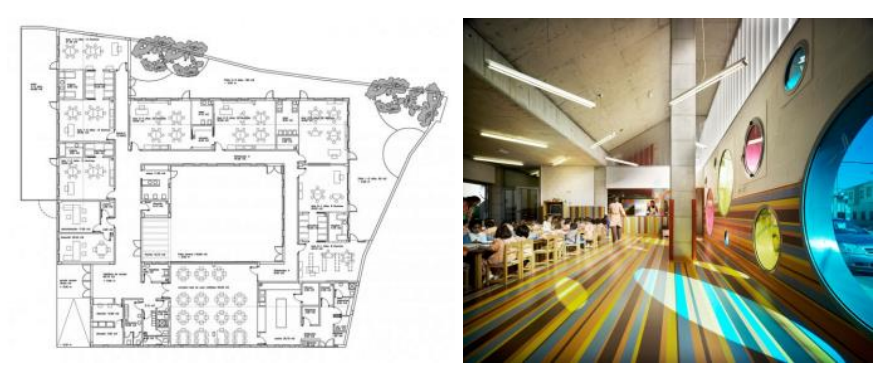

Fig. 2 Floor plan and interior - Kindergarten 8Units Velez-Rubio ${ }^{2}$

The closed pedagogical concepts provide for the child care in fixed groups - children of the same or similar age, placed in two separate group rooms. The example of the kindergarten in Monthey, Switzerland (Fig. 3). The group rooms play an important role in the semi-open concepts, because children begin their day there and realize various group activities. However, this is not the only place where children spend their time. In the day, the group rooms can be opened, and children will be allowed to play inside the building if the foyers and hallways are adequately designed, or they can be entertained in the multifunctional spaces, as it is the case in the kindergarten El Porvenir Social in Bogota, Columbia (Fig. 4). As opposed to this, in the open concept, there are no separate classrooms, but only the spaces for certain functions, which must be adequately spacious and shaped. Such concept is implemented in the small capacity kindergartens, such as Fagerborg kindergarten, Oslo, Noway (Fig. 5).
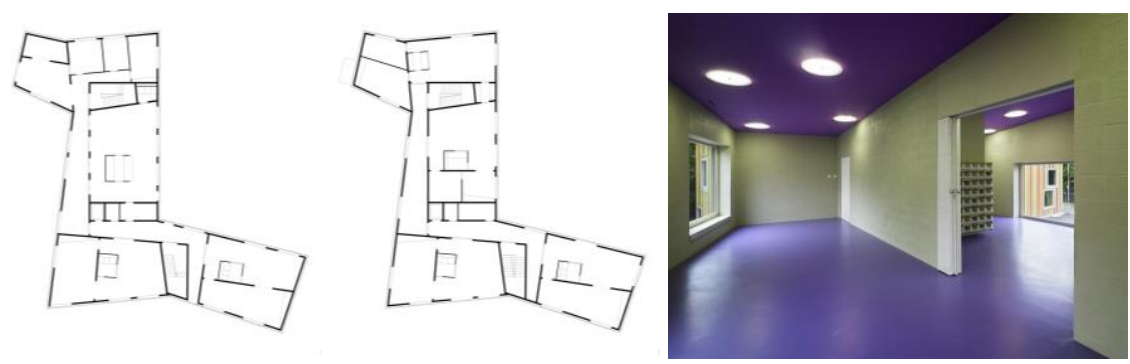

Fig.3 Floor plans and interior - Monthey Kindergarden ${ }^{3}$

\footnotetext{
${ }^{2}$ http://www.archdaily.com/129662/kindergarten-8units-velez-rubio-losdeldesierto/, Retrieved November 2013

${ }^{3}$ http://www.archdaily.com/79449/monthey-kindergarden-bonnard-woeffray-architectes/, Retrieved November 2013
} 

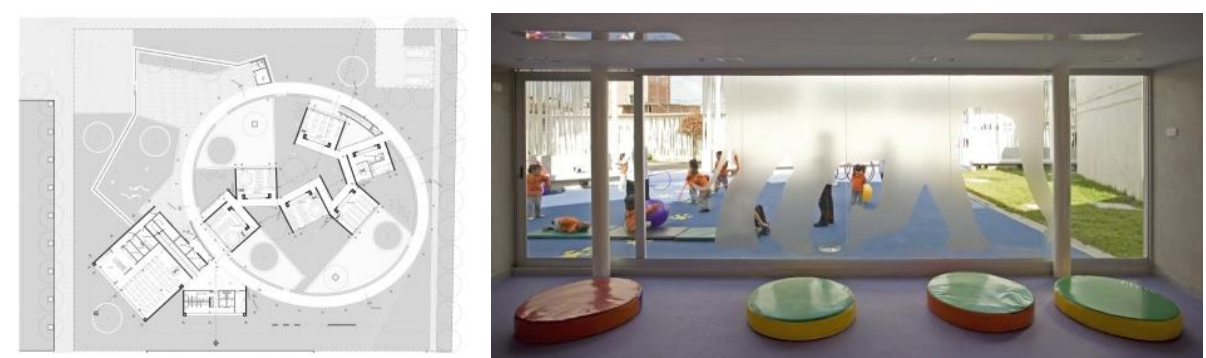

Fig. 4 Floor plan and interior - El Porvenir Social Kindergarden ${ }^{4}$
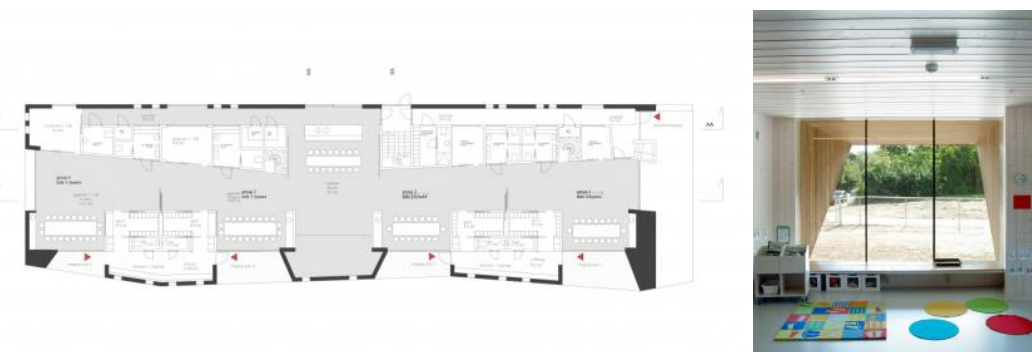

Fig. 5 Floor plan and interior - Fagerborg Kindergarten ${ }^{5}$

When a large number of children is accommodated in the same room throughout a day, and if there is no separate space for other activities and dining, the space may become crowded. For this reason, either several rooms with the size larger than the standard one are designed, or other rooms outside the group rooms are provided, such as the kindergarten in Zaragoza, Spain. (Fig. 6), where the system of sliding doors connects the rooms to the corridors and to a multifunctional hall. The gallery space is particularly good for these purposes. This was internalized in the example of the kindergarten in Ternitz, Austria (Fig. 7). The gallery space allow additional space for isolation, and allow the children to experience the space from a different perspective. The space below the gallery can be transformed into a retreat for peaceful games.
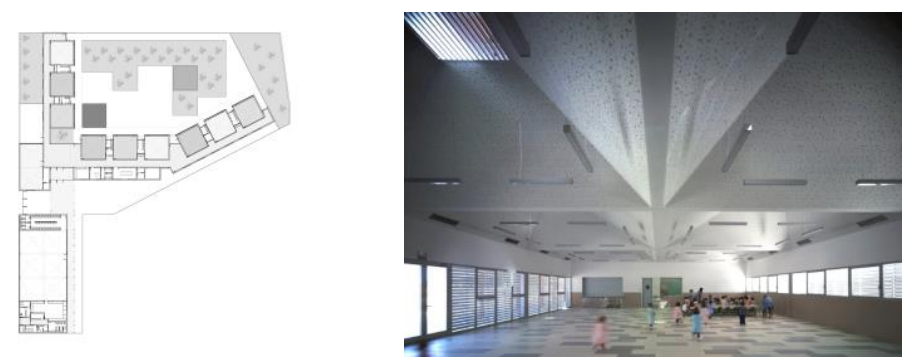

Fig. 6 Floor plan and interior - Rosales del Canal Kindergarden ${ }^{6}$

\footnotetext{
${ }^{4}$ http://www.archdaily.com/89896/el-porvenir-social-kindergarden-giancarlo-mazzanti/, Retrieved November 2013

${ }^{5}$ http://www.architecturenewsplus.com/projects/2416, Retrieved November 2013
} 


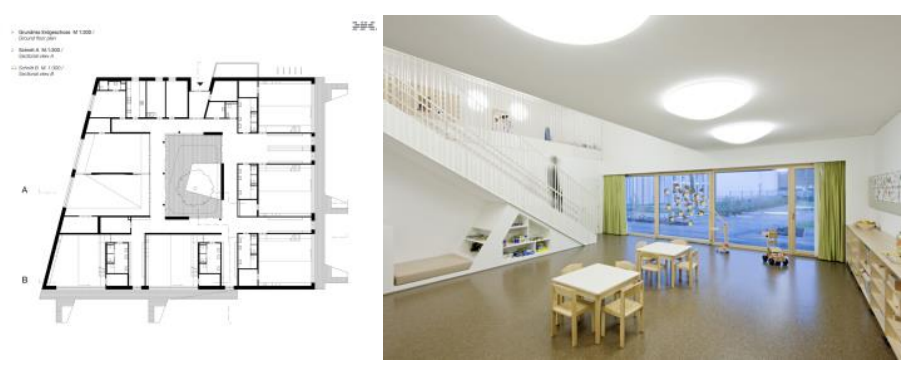

Fig. 7 Floor plan and interior - Kindergarten In Ternitz ${ }^{7}$

Connecting two group rooms with retractable partitions proved to be a good principle. A series of rooms can be flexibly used in this case, and monitoring of the children is simplified. Glass walls or interior fenestration between the classrooms and the play areas in the halls provides an exciting visual connection to the children, and permits the personnel an easier supervision. A good example of such concept is the kindergarten Segrt Hlapic in Zagreb, Croatia (Fig. 8). The classrooms have optimal natural lightning and a direct exit to a terrace. In many cases, the activities during the day do not unfold in one group only or in one room. The children can move around different functional spaces. Multifunctional rooms are neutral, so they can change as needed, leaving the space for children and their creative ideas. Such spaces become the places where children can eat together, which saves space since it is not necessary to provide separate dining rooms for children.
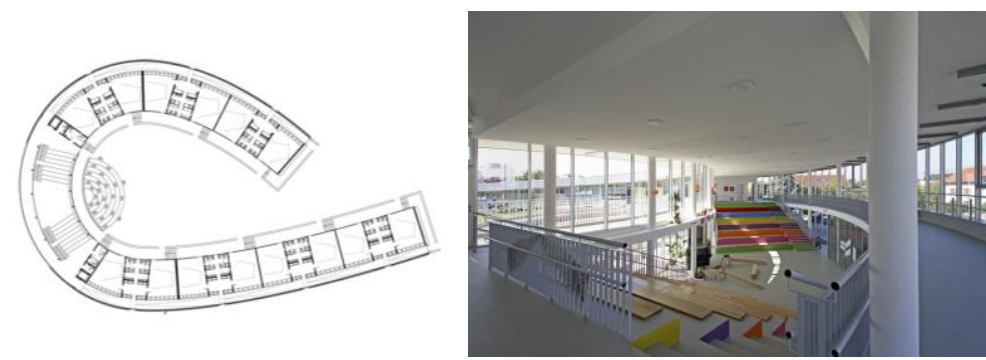

Fig. 8 Floor plan and interior - Segrt Hlapic Kindergarten ${ }^{8}$

The entrances and locker rooms provide communication and exchange of information. Locker rooms should have adequate dimensions, since a large number of children arrive at the same time, and they can be crowded. The storage space for children's stuff should be designed, and in ideal case, the locker rooms should be designed so as to have an exit door leading directly outside. The stairs are particularly attractive for children of all ages, since they provide interesting variously elevated view points. Low steps of the stairs with wide tread are particularly important as play areas. Low steps also reduce the injury hazard. The corridor connecting the rooms should be expanded to a foyer or hall which can

\footnotetext{
${ }^{6}$ http://www.archdaily.com/55546/rosales-del-canal-kindergarden-magen-arquitectos/, Retrieved November 2013

${ }^{7}$ http://www.archdaily.com/110822/kindergarten-in-ternitz-alleswirdgut-architektur/, Retrieved November 2013

${ }^{8} \mathrm{http} / / /$ www.radionica-arhitekture.hr/ \#djecji_vrtic_segrt_hlapic, Retrieved November 2013
} 
serve as area for socialization. In numerous cases, the niches or expanded areas or low steps of the stairs are sufficient in articulating such large spaces and in rendering them exciting for children. If the corridor is sufficiently wide, it can accommodate the lockers and it can serve as a playground, or it can be designed as well-lit multifunctional space.

\section{INTERIOR REMODELING}

The importance assigned to children is reflected in the quality of care created in preschool institutions. The positive development can be seen in analyzed examples, where the holistic aspect of the development of a child's personality plays an important part. In the future, not only the number of the newly constructed facilities for the child care will be valued, but the preschool institutions will be innovated through remodeling, which will take satisfaction of various children's psychological needs of into consideration. In this paper, the innovations in the interior of the preschool institution „Bajka" includes the level of interventions addressing revitalization and reconstruction of the existing space of group rooms which includes their functional and spatial remodeling. The criteria determining the potential model of innovation were created in regard of the architectonic concepts of preschool institutions in the context of psychological needs and of the data obtained through the analysis of the current status.

Kindergarten "Bajka" was built in 1975 and is the typical representative of the kindergarten architecture of that time (Fig. 9). Kindergarten "Bajka" has an area of $725 \mathrm{~m}^{2}$, and is currently hosting 150 children. There are many buildings of similar form and structure and related function that have been built in the same period on the wider area of the city of Niš (kindergarten „Plavi Čuperak" and kindergarten „Kolibri”). The kindergarten "Bajka" was chosen as a most representative example, in order to apply the obtained results from this research onto the other kindergartens with similar characteristics.
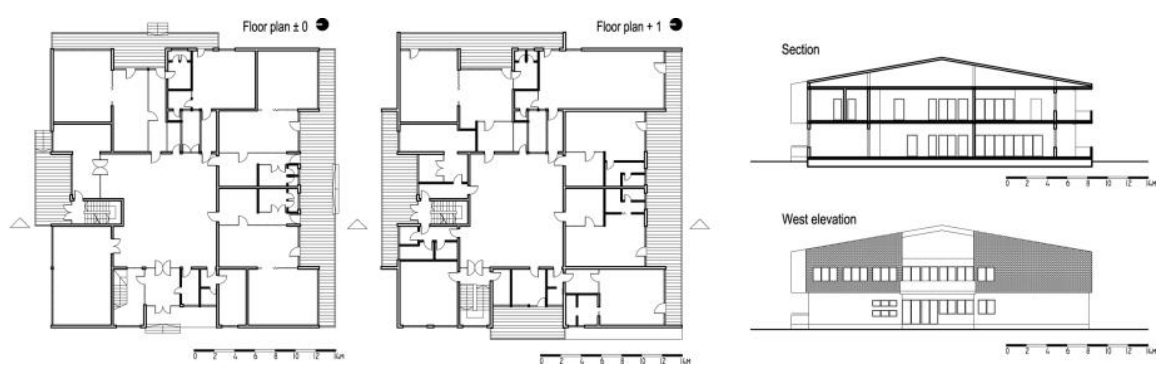

Fig. 9 Floor plans, section and elevation of the "Bajka" kindergarten

Analyzing the current state of affairs, the conclusion was drawn concluded that the kindergarten „Bajka" in the architectonic, i.e. spatial-functional and formal terms does not satisfy the contemporary psychological requirements of children's stay in the preschool facilities. For this reason, remodeling of kindergartens reflect in the improvement of these requirements, and by this in the improvement of the ambience values and quality of space. Considering the observed unfavorable conditions in this kindergarten, the initial priorities in remodeling of the interior were identified: modernization of furniture and equipment, 
application of appropriate materials (quality, texture, color), provision of multifunctionality of the block with teaching implements and spatial linking of the group rooms and surrounding facilities (Fig. 10 and Fig. 11). The architectonic expression comprises "playfulness" and the authenticity of the form, its multi-layered interpretability but also the visual harmony, inclusion of various types of materials and their combination, austere diversity and warmth of the applied colorations, through association with the topics a child can be emotionally related to.
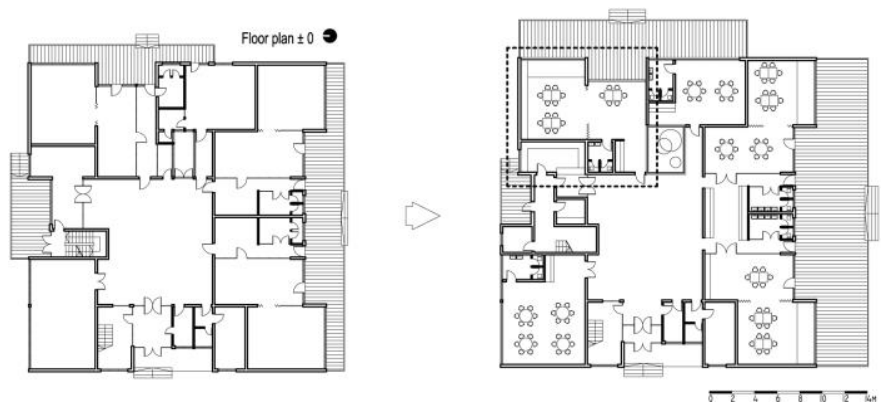

Fig. 10 Intervention in the interior organization of space

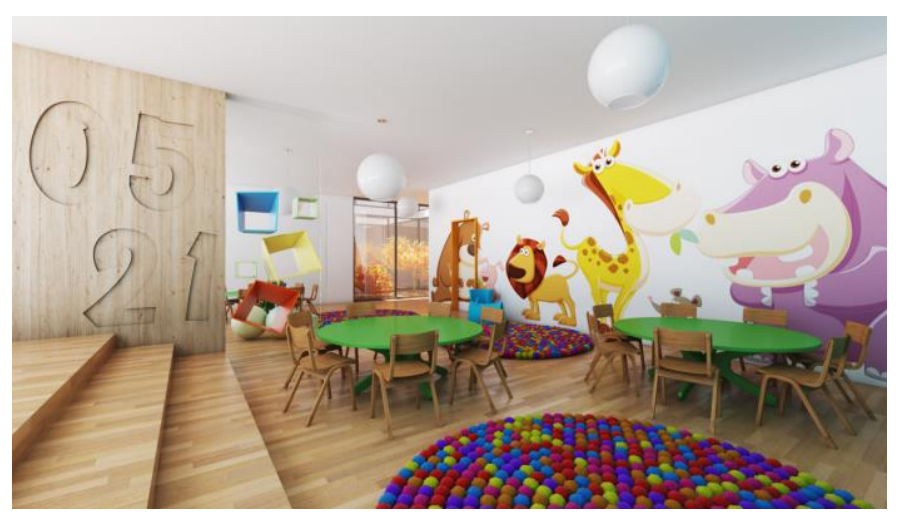

Fig. 11 Proposition for remodeling of the interior of the group room in the kindergarten „Bajka"

\section{CONCLUDING REMARKS}

Particular attention should be paid to shaping and materialization of the interior space where children spend time, since the way children experience it is important for their development and since it has a positive impact on it. Architectural and interior space elements with the intention of supporting physical characteristic of space that represent children's requirements define an identity in interior space of kindergarten. Architectonic organization of space where children stay in preschool institutions and emotional needs as 
a developmental factor at this age, pose certain requirements in respect to the physical environment. It is necessary that the space where children spend time is organized and equipped so that it supports a child and provides privacy, shelter and isolation so that it could express its emotion and gain confidence. When it comes to the architectonic elements of the space for stay, the structural characteristics of these environments refer to the specificity of designed architectonic elements of interiors, in the spatial plane zones.

From the psychological aspects of the stay of children in the preschool facilities, the proposition for remodeling of the interior of the kindergarten „Bajka" is presented in this paper. The practical model of innovating the interior was primarily established in cancelling the mono-functionality of certain parts of the architectonic plan, and by linking the certain activities. In order for the spaces where children stay to be agreeable, a space where the children would like to spend time was designed. The quality of preschool education in one part refers to the quality of architectonic design, that is, the quality of organization and materialization of designed physical structures in preschool spaces. Certain conclusions from this research can be implemented in innovation of other kindergartens in Niš, but also those with the similar characteristics in the whole Republic of Serbia as well.

\section{REFERENCES}

1. Dudek, M. (2000). Kindergarten architecture: space for the imagination. Taylor \& Francis. pp. 217.

2. Dudek, M. (Ed.). (2005). Children's spaces. Routledge. pp. 256.

3. Dudek, M., \& Baumann, D. (2008) Schools and kindergartens: a design manual. Birkhäuser.

4. Edwards, C. (1993). The hundred languages of children: The Reggio Emilia approach to early childhood education. Ablex Publishing Corporation, 355 Chestnut Street, Norwood, NJ 07648.

5. Edwards, C. P., Gandini, L., \& Forman, G. (Eds.). (1998). The hundred languages of children: The Reggio Emilia approach: Advanced reflections. Greenwood Publishing Group. pp. 324.

6. Evans, G. W. (2004). The environment of childhood poverty. American psychologist, 59(2), pp. 77.

7. Evans, G. W. (2006). Child Development and the Physical Environment. Annual Review of Psychology Vol. 57: pp. 423-451.

8. Evans, G. W., Brauchle, G., Haq A., Stecker R., Wong K. and Shapiro E. (2007). Young Children's Environmental Attitudes and Behaviors. Environment and Behavior 39 (5), pp. 635-659.

9. Hart, R. (1979). Children's experience of place. Irvington, pp.518.

10. Hart, R. A. (1997). Children's participation: the theory and practice of involving young citizens in community development and environmental care. Earthscan, pp. 219.

11. Ivanović - Šekularac, J. (2000). Predškolske ustanove i komfor, Zadužbina Andrejević, Beograd, pp. 114

12. Milosević, V., Nikolić, V., Stanković, D. (2012) Kindergarten Remodeling as a Part of The Kindergarten Revitalization Process, UACEG2012: Science \& Practice Volume 1, University of Architecture, Civil Engineering and Geodesy, Sofia, pp.159-164.

13. Moore, G. T. (1985). The designed environment and cognitive development: A brief review of five domains of research. Children's Environments Quarterly, 2(2), pp. 26-33.

14. Moore, G. T., Lane, C. G., Hill, A. B., Cohen, U., \& McGinty, T. (1994). Recommendations for child care centers. Center for Architecture and Urban Planning Research, University of Wisconsin-Milwaukee, Milwaukee, WI 53201-0413.

15. Moore, G.T. (1986). Effects of the spatial definition of behavior settings on children's behavior: A quasi-experimental field study, Journal of Environmental Psychology, 6, pp. 205-231.

16. Moore, G.T. (1987). The physical environment and cognitive development in child-care centers, Spaces for children: The built environment and child development, pp. 41-72.

17. Nikolić, V., Milošević, V., Stanković, D. (2013). Remodeling Kindergartens in the Context of Energy Efficiency, 5th International Conference on Contemporary Problems of Architecture and Construction, Saint-Petersburg, Russia, Saint-Petersburg, State University of Architecture and Civil Engineering, Conference Proceedings Vol. 1, pp. 83-87. 
18. Petković, N., Kondić, S., Tanić, M. (2012). Conversion Possibilities of Residual Buildings into Preschool Facilities: Case Study - "English Kindergartens" in Nis, Proceedings of the 4th International Conference: Civil Engineering - Science and Practice, Zabljak, pp. 1557-1564.

19. Read, M. A., Sugawara, A. I., \& Brandt, J. A. (1999). Impact of Space and Color in the Physical Environment on Preschool Children's Cooperative Behavior. Environment and Behavior 31(3), pp. 413-428.

20. Stanković, D. (2003). Aspects of evaluation of the manner of materialization and degree of economy in design of the central units of institutions for the children. Zbornik radova Građevinsko-arhitektonskog fakulteta, Niš, (19), pp. 53-62.

21. Stanković, D. (2007). Properties of dwelling space in the function of the psychological development of children. Zbornik radova Građevinsko-arhitektonskog fakulteta, Niš, (22), pp.175-180.

22. Stanković, D. (2008). Space in the Function of Psychological Stability of a Child. Facta universitatisseries: Architecture and Civil Engineering, Niš, 6(2), pp. 229-233.

23. Stanković, D. (2011). The environmental revitalization of the space for children. Facta universitatisseries: Architecture and Civil Engineering, Niš, 9(3), pp. 481-489.

24. Stanković, D., Milojković, A., \& Tanić, M. (2006). Physical environment factors and their impact on the cognitive process and social behavior of children in the preschool facilities. Facta universitatisseries: Architecture and Civil Engineering, Niš, 4(1), pp. 51-57.

25. Stanković, D., Stojić, J. (2007). Psycho-Developing Needs of Children and Spatial Features for Children's Stay, Facta Universitatis, Series Architecture and Civil Engineering, Niš, 5(1), pp. 71-75.

26. Trancik, A.M., \& Evans, G.W. (1995). Spaces fit for children:competency in the design of daycare center environments. Children's Environments, 12(3), pp. 43-58.

27. Weinstein, C. S. (1987). Designing preschool classrooms to support development, Spaces for children: The built environment and child development, pp. 159-185.

28. Wohlwill, J. F., \& Heft, H. (1987). The physical environment and the development of the child. Handbook of environmental psychology: Vol. 1, pp. 281-328.

\section{REMODELOVANJE ENTERIJERA PREDŠKOLSKIH USTANOVA U KONTEKSTU UNAPREĐENJA AMBIJENTALNIH VREDNOSTI I KVALITETA PROSTORA}

Polazeći od stava da se u koncipiranju, projektovanju i opremanju prostora za boravak dece doprinosi kvalitetu prostora u kojoj deca borave rad se bavi remodelovanjem enterijera u procesu revitalizacije postojećih predškolskih ustanova. Problematici se pristupilo na osnovu kritika i studija psiholoških aspekata boravka dece u predškolskim ustanovama. Osnovni cilj predviđenog istraživanja je utvrđivanje praktičnog modela inoviranja enterijera predškolskih ustanova u Nišu, kao tipičnoj urbanoj sredini. Mogućnosti inoviranja sadgledane su na predloženom remodelovanju enterijera predškolske ustanove „Bajka". Zaključci iz ovog istraživanja mogu se koristiti kao smernice za remodelovanje enterijera drugih obdaništa izgrađenih $u$ istom periodu.

Ključne reči: predškolske ustanove, revitalizacija, remodelovanje, inoviranje, enterijer. 